\title{
Erratum to: IKK-related genetic diseases: probing NF-кB functions in humans and other matters
}

\author{
Anna Senegas · Jérémie Gautheron • \\ Alice Gentil Dit Maurin • Gilles Courtois
}

Published online: 24 February 2015

(C) Springer Basel 2015

Erratum to: Cell. Mol. Life Sci.

DOI 10.1007/s00018-014-1793-y

Unfortunately, the given and family name of one of the coauthors, Dr. Alice Gentil Dit Maurin, was incorrectly published in the original publication. The correct given name and family name should read as 'Alice' and 'Gentil Dit Maurin', respectively.

The online version of the original article can be found under doi:10.1007/s00018-014-1793-y.

A. Senegas · A. Gentil Dit Maurin · G. Courtois INSERM U1038, iRTSV, CEA Grenoble, Grenoble, France

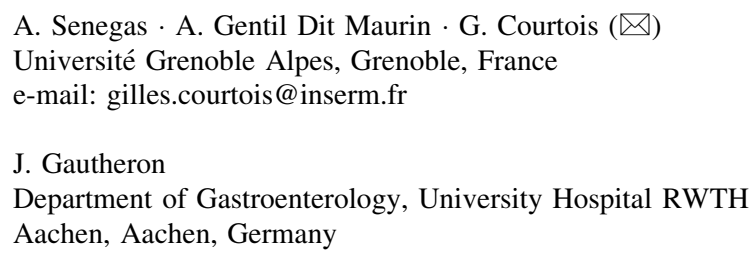

